\title{
POLA PENGASUHAN ANAK PADA MASYARAKAT ARAB SUNDA DI KABUPATEN PURWAKARTA
}

\author{
Oleh Yanti Nisfiyanti \\ Balai Pelestarian Sejarah dan Nilai Tradisional Bandung \\ Jln. Cinambo No. 136 Ujungberung Bandung \\ Email: yantinisfiyanti@ymail.com
}

\begin{abstract}
Abstrak
Keluarga merupakan kesatuan sosial terkecil tempat pertama kali seorang manusia menerima pengasuhan dan pendidikan dari orang tua. Dalam pola pengasuhan dan pendidikan anak, terdapat proses sosialisasi nilai-nilai yang disampaikan orang tua kepada anak. Pola pengasuhan anak pada setiap keluarga membentuk perkembangan dan karakter anak.

Pada pembentukan karakter anak lebih ditentukan oleh budaya orang tua. Dalam pola pengasuhan anak pada keluarga keturunan Arab Sunda proses sosialisasi nilai-nilai ditentukan oleh budaya akulturasi Arab dan Sunda.
\end{abstract}

Kata Kunci: keluarga, pendidikan, sosialisasi, akulturasi.

\begin{abstract}
Family is the smallest social unity, where the first time humans were given care and education by their parents. In the child caring and education pattern, there's a socialization. Process of these values which is given by the parents to the children. These pattern are exist in every family and shaping children's character and development.

Same as the patterns in Sundanese-Arabian descendence families, there's also a socialization process of values from the parent's to children. Those values originated from two cultures, Arabian and Sundanese.
\end{abstract}

Keywords : family, education, socialization, aculturation.

\section{A. Pendahuluan}

Pengasuhan anak adalah bagian terpenting dalam proses sosialisasi, yaitu proses orang tua mempersiapkan anak untuk menjadi warga masyarakat. Proses sosialisasi tersebut tidak sekadar merawat dan menjaga anak, tetapi pendidikan moral dengan menanamkan nilai-nilai sejak anak dapat berinteraksi dengan orang tuanya. Pada sebagian masyarakat, pendidikan moral tersebut dilakukan sejak anak masih di dalam kandungan ibunya.
Diyakini bahwa Ibu yang sedang hamil apabila berperilaku baik, maka anak yang dikandungnya kelak akan berperilaku baik pula. Adapun pendidikan yang diperkenalkan kepada anak meliputi etika, kesopansantunan, kedisiplinan, kebersihan, dan tatakrama yang didasarkan pada adat masyarakat setempat. Dengan berbekal pengasuhan dan pendidikan dalam keluarga, diharapkan anak dapat beradaptasi dengan lingkungan di sekitarnya. 
Masyarakat adalah kesatuan sosial yang lebih kompleks. Adanya keragaman budaya yang mempengaruhi perilaku masyarakat, akan berpengaruh pula pada pola pengasuhan anak. Demikian pula adanya keragaman pengetahuan yang diperoleh oleh setiap keluarga, akan berpengaruh pada pola pengasuhan anak di setiap keluarga. Salah satu kelompok masyarakat di Kabupaten Purwakarta, Jawa Barat adalah masyarakat keturunan Arab Sunda. Kelompok masyarakat tersebut memiliki pengetahuan, pola perilaku, dan nilai-nilai yang sedikit berbeda dengan kelompok masyarakat Sunda di sekitarnya. Sebagai kelompok masyarakat yang lahir dari akulturasi dua budaya, masyarakat Arab Sunda memiliki pola pengasuhan yang berbeda dengan pola pengasuhan pada masyarakat di sekitarnya. Pola pengasuhan anak pada masyarakat Arab Sunda belum banyak diketahui sehingga perlu didokumentasikan untuk diketahui oleh khalayak umum. Untuk itu permasalahan dirumuskan dalam pertanyaan sebagai berikut:

- Bagaimana pola pengasuhan anak pada masyarakat Arab Sunda di Kabupaten Purwakarta?

- Bagaimana cara mewariskan nilai-nilai budaya kepada anak?

Tujuan penelitian ini secara umum adalah untuk mengetahui tradisi masyarakat Arab Sunda di Kabupaten Purwakarta, sedangkan tujuan utamanya adalah mendokumentasikan pola pengasuhan anak pada masyarakat Arab Sunda di Kelurahan Nagri Kidul, Kecamatan Purwakarta, Kabupaten Purwakarta.

Adapun ruang lingkup materi meliputi cara-cara orang tua mengajarkan, membiasakan anak dalam hal kedisiplinan, kebersihan, tatakarama, serta mewariskan nilai-nilai dan norma yang berlaku. Pola interaksi meliputi anak dengan keluarga inti, anak dengan keluarga besar dan anak dengan bukan kerabat; ruang lingkup wilayah meliputi Kelurahan Nagri Kidul yang mayoritas penduduknya warga keturunan Arab Sunda; ruang lingkup informan meliputi keluarga inti: ibu, bapak, dan anak sebagai informan biasa yang terlibat langsung dalam proses pola pengasuhan anak. Sebagai informan kunci adalah tokoh masyarakat setempat yang diharapkan bisa menjelaskan tradisi masyarakat Arab Sunda di wilayahnya.

Dalam penelitian ini digunakan metode kualitatif, yaitu pengumpulan data yang diikuti dengan analisis dan interpretasi data. Adapun penganalisisan secara deskriptif, yaitu menjelaskan masalah yang sedang berlangsung.

\section{B. Hasil dan Bahasan}

Kelurahan Nagri Kidul, salah satu wilayah di Kecamatan Purwakarta yang sejak tahun 1956 penduduknya $99 \%$ para pedagang keturunan Arab. Pada tahun 1956 tersebut merupakan generasi ketiga. Seiring berjalannya waktu, penduduk keturunan Arab di Kelurahan Nagri Kidul berkembang. Saat ini Kelurahan Nagri Kidul terdiri atas 10 Rukun Warga (RW), di antaranya RW 01, 03, 09, dan RW 10, yang mayoritas berpenduduk keturunan Arab. Terbanyak keturunan Arabnya adalah RW 01 (60\% keturunan Arab dan $40 \%$ Sunda). Sejak lama keturunan Arab berbaur dengan penduduk pribumi, bahkan di antaranya mempersunting wanitawanita dari penduduk setempat. Keturunan Arab di Kelurahan Nagri Kidul disebut kaum Jamaah. Kaum Jamaah aktif dalam pendidikan keagamaan untuk anak-anak usia sekolah dan syiar agama Islam di lingkungan setempat.

Adanya perkawinan antara keturunan Arab dan Sunda sejak dahulu hingga sekarang mengakibatkan percampuran budaya (akulturasi) yang tercermin dalam kehidupan masyarakat keturunan Arab Sunda di Kelurahan Nagri Kidul. Ketika 
mereka mengadakan selamatan seperti pernikahan atau perayaan hari besar Islam akan tersaji makanan olahan khas Arab, seperti nasi kebuli, sayur marag, atau kaak. Dalam acara pernikahan biasanya ditampilkan hiburan, seperti orkes gambus dan marawis. Selain itu, dalam kehidupan sehari-hari di lingkungan keluarga keturunan Arab Sunda ini sudah tidak asing istilah kekerabatan atau sapaan Arab dan Sunda. Kedua bahasa tersebut digunakan dalam bersosialisasi.

Proses sosialisasi yang berlaku dalam keluarga keturunan Arab Sunda di Kelurahan Nagri Kidul berlangsung melalui interaksi antaranggota keluarga yang menunjukkan pola-pola interaksi.

\section{Pola Interaksi}

Manusia disebut sebagai animal symbolicum (Kusnaka, 1992: 36), yaitu seperti hewan yang selalu ingin berkoloni. Sebagai makhluk yang selalu berkumpul, berinteraksi, dan bekerja sama, maka manusia adalah makhluk sosial yang mempertahankan kelangsungan hidupnya di dunia dengan bekerja sama dengan manusia lainnya untuk saling membantu. Untuk kelancaran hubungan tersebut manusia memiliki tata cara yang mengatur perilaku mereka, baik sebagai anggota keluarga maupun masyarakat.

Pola interaksi dalam keluarga keturunan Arab Sunda berlangsung dengan baik. Dalam berkomunikasi mereka menggunakan tiga bahasa, yaitu bahasa Sunda, bahasa Indonesia, dan bahasa Arab.

\section{a. Interaksi antara Anak dan Bapak}

Pada umumnya, seorang bapak pada keluarga keturunan Arab Sunda menjalani kehidupan sebagai pedagang di pasar, yaitu Pasar Rebo. Karena kesibukannya sebagai pencari nafkah, hubungan Bapak dengan anak-anak tidak seintensif hubungan anak dengan ibunya yang sebagian besar waktunya berada di rumah. Oleh karena itu, anak lebih sering berinteraksi dengan Ibu daripada dengan Bapak. Dalam berkomunikasi anak menggunakan bahasa yang dicontohkan oleh orang tuanya. Pada umumnya, bahasa Sunda diperoleh dari garis ibu sehingga anak dapat berbicara bahasa Sunda, sedangkan bahasa Arab diperoleh dari garis Bapak. Adapun bahasa Indonesia selain diperoleh dari orang tua, didapatkannya dari lingkungan sekolah atau media elektronik. Penggunaan bahasa Arab dalam kehidupan sehari-hari cukup terbatas, misalnya anak memanggil Bapak dengan $A b i$ dan Ibu dengan Umi. Atau ketika mengajak salat: "Ayo ussali!" lalu mengajak teman masuk ke rumah "Dekul!"

Hubungan antara anak dan Bapak sewaktu anak masih kecil, baik anak lakilaki maupun anak perempuan relatif dekat. Kecuali pada hal-hal yang bersifat normatif, perlakuan Bapak kepada anak perempuan tidak sebebas Ibu. Keterbatasan sikap Bapak kepada anak perempuan lebih tegas pada saat anak yang perempuan beranjak remaja. Umumnya, Bapak bersikap tegas, baik kepada anak laki-laki maupun anak perempuan sehingga kasih sayangnya tidak terlihat. Anak laki-laki yang beranjak remaja sudah bisa melakukan aktivitas bersama Bapaknya, seperti salat berjamaah di masjid dan berziarah ke makam leluhur. Sementara anak perempuan lebih banyak melakukan kegiatan bersama ibunya. Dalam hal pergaulan, baik anak laki-laki maupun anak perempuan, lebih terbuka kepada teman-teman sebayanya daripada kepada orang tuanya.

\section{b. Interaksi antara Anak dan Ibu}

Ibu pada keluarga keturunan Arab Sunda umumnya tidak bekerja, hanya beberapa yang membantu suaminya berjualan di pasar. Meskipun demikian, Ibu 
lebih banyak berada di rumah daripada Bapak. Oleh karena itu, Ibu mempunyai waktu banyak untuk berinteraksi dengan anaknya. Hal itu mempengaruhi sikap anak terhadap ibu. Anak tidak merasa sungkan dalam berbicara dan bersikap terhadap ibunya.

Kedekatan hubungan ibu dan anak menjadi media penghubung antara anak dan Bapak. Di antaranya menyampaikan hal-hal yang menyangkut keperluan anak kepada Bapaknya. Sebaliknya, Bapak mendelegasikan Ibu untuk mengasuh dan mendidik anaknya, menegur anaknya apabila berperilaku tidak baik atau melalaikan kewajiban beribadah sewaktu Bapak tidak sedang berada di rumah.

Sementara itu, anak menjadi tahu segala sesuatu pertamakali diperolehnya dari Ibu. Sejak kecil, anak terbiasa melihat aktivitas sehari-hari ibunya dan setelah remaja anak perempuan mulai terlibat dalam aktivitas tersebut. Dalam keluarga keturunan Arab Sunda pendidikan agama sudah diterapkan sejak anak pra sekolah dengan mengajak anak ketika melaksanakan ibadah, seperti salat lima waktu berjamaah dan mengaji. Selama Bapak tidak ada di rumah, Ibulah yang memegang peranan.

\section{c. Interaksi antara Anak dan Saudara Kandung}

Pasangan suami istri keturunan Arab Sunda umumnya memiliki anak lebih dari dua orang. Jarak usia anak pertama ke anak kedua dan ketiga tidak jauh. Dengan perbedaan usia yang tipis, memungkinkan anak dan saudaranya bermain bersama. Sang kakak yang sudah dapat mengasuh akan dititipi adiknya saat ibu sedang sibuk. Misalnya, mengajak bermain atau menyuapi adiknya. Sikap saling menghargai dan menghormati ditanamkan oleh orang tua dalam kehidupan sehari-hari. Seorang kakak harus mengalah kepada adiknya dan adik harus hormat kepada kakaknya. Pada bulan Ramadhan ketika umat Islam melaksanakan ibadah puasa, anak yang sudah sekolah mulai belajar berpuasa secara bertahap. Meskipun tidak puasa, makan dan minum secara bebas di depan saudaranya tidak diperkenankan bagi sang adik yang sudah bersekolah.

Hubungan antarsaudara kandung berbeda jenis yang sudah menginjak remaja tidak seakrab waktu mereka masih kecil. Biasanya, komunikasi di antara mereka bersifat seperlunya karena masing-masing merasa malu. Selain itu, mereka tidak mau berjalan bersama-sama apabila bepergian, sekalipun bersama orang tuanya. Perubahan fisikologis dan psikologis dari anak-anak menjadi remaja merupakan faktor penyebabnya.

\section{d. Interaksi antara Anak dan Kerabat}

Dalam keluarga Arab Sunda, hubungan kekerabatan dapat dikatakan baik. Dalam arti interaksi anak dengan kerabat cukup lancar karena tempat tinggal mereka umumnya berada dalam satu wilayah, bahkan satu rumah. Oleh karena itu, kesempatan untuk bertemu dan berkomunikasi dengan kerabat sangat memungkinkan. Akan tetapi, apabila tempat tinggal dengan kerabat berjauhan, pertemuan sekali-kali saja, seperti saat selamatan, Hari Raya Idul Fitri, dan harihari penting lainnya. Oleh karena itu, interaksi dengan kerabat yang jauh tempat tinggalnya, tidak sesering dengan kerabat yang berdekatan tempat tinggalnya. Salah satu interaksi anak dengan kerabat adalah dengan kakek dan nenek atau paman.

Adanya hubungan yang jauh karena sesuatu hal antara anak dengan orang tua biasanya anak akan dekat dengan kerabat sebagai keluarga kedua. Anak yang sejak kecil tinggal dengan kerabat akan lebih mudah berinteraksi dengan anggota kerabat lainnya. Sebagai 
contoh, ada anak yang tinggal dengan kakek, nenek, dan paman karena ibunya sudah meninggal, sedangkan ayahnya menikah lagi. Ada pula anak yang tinggal dengan orang tua dan kerabat lainnya. Pada kondisi demikian, interaksi antara anak dan kerabat terjadi setiap hari.

Anak dalam keluarga campuran Arab Sunda mengenal kerabatnya melalui orang tua. Sejak anak-anak, mereka telah diperkenalkan dengan kerabat melalui kata sapaan Arab dan kata sapaan Sunda. Misalnya, Kata sapaan Arab Zit (=kakek), Zidah (=nenek), Ami (= paman dari Bapak), atau Hal (paman dari Ibu), dan Halati (= Bibi) digunakan kepada anggota kerabat yang berdarah Arab. Kata sapaan Sunda Aki, Nini, Emang, Bibi, dan Uwa digunakan kepada anggota kerabat yang berdarah Sunda. Pengetahuan anak tentang kata sapaan diperoleh dari orang dewasa ketika menyapa anggota kerabat.

\section{e. Interaksi antara Anak dan Selain Kerabat}

Anak usia sekolah, 7 tahun hingga 14 tahun, tidak hanya berinteraksi dengan anggota keluarga inti dan kerabatnya, tetapi berkembang hingga lingkungan sekolah dan tetangga. Di sekolah anak berinteraksi dengan para guru dan teman sebayanya. Dalam pergaulan dengan teman sebanyanya, anak mengenal persahabatan dan persaingan, kondisi yang saling bertentangan. Dalam berinteraksi dengan para guru, anak mengenal bagaimana cara bersikap hormat dan patuh. Selain itu, di sekolah anak mengenal tanggung jawab dalam mengerjakan tugas-tugas yang diberikan oleh para guru serta mengenal kedisiplinan dalam menaati peraturan sekolah, seperti tidak terlambat datang ke sekolah, harus mengenakan seragam, dan harus melaksanakan piket kebersihan di kelasnya. Apabila anak melanggar disiplin sekolah, maka ia akan menerima teguran dari guru. Bahkan apabila pelanggaran dianggap sudah berat, maka anak akan menerima sanksi dari sekolah.

Anak-anak keturunan Arab Sunda di Pasar Rebo umumnya bersekolah di sekolah pendidikan Islam, seperti MAI (Madrasah Arabiah Islamiah) dan MAN (Madrasah Aliah Negeri) yang setingkat SMA. Yang bersekolah di sekolah tersebut terdapat pula anak-anak bukan keturunan. Demikian pula guru-guru yang mengajar di sekolah tersebut terdapat pula bukan keturunan. Hubungan anak, baik dengan teman sebaya maupun guru-gurunya tersebut berlangsung dengan baik. Namu demikian, ada pula yang bersekolah di SMP Negeri. Dalam berkomunikasi, mereka menggunakan bahasa Indonesia bercampur dengan bahasa Sunda dan bahasa Arab.

Selain berinteraksi dalam lingkungan sekolah, anak berinteraksi dengan tetangga. Saat pergi dan pulang sekolah atau ketika bermain di luar rumah, anak akan bertemu dengan para tetangga di sekitar rumahnya. Anak akan tahu siapa tetangga di sebelah dan di depan rumahnya lewat pengamatannya atau percakapan antara orang tua dan tetangganya. Adapun dengan tetangga yang berjauhan jarak rumahnya, anak berinteraksi dengan pemilik warung atau toko saat ia disuruh orang tuanya berbelanja. Seperti halnya sikapnya kepada guru, dengan tetangga pun ia harus bersikap baik dan menjalin pertemanan dengan anak-anak di sekitarnya.

Pada keluarga keturunan Arab Sunda di Pasar Rebo, anak berinteraksi dengan tetangga tampak lancar. Hal itu berlaku pada anak yang orang tuanya senang bergaul dengan tetangga. Ibu-ibu yang tidak mempunyai kesibukan di luar rumah, satu hingga dua ibu membawa anaknya di bawah usia 9 tahun ke warung dekat rumah. Sambil berbelanja atau jajan, anaknya bermain di sekitar tempat 
itu. Pergaulan antara anak keturunan Arab Sunda dan penduduk setempat (bukan keturunan Arab) cukup terbuka karena terbawa orang tua. Selain itu, orang tua tidak banyak melarang anaknya bergaul dengan siapa saja selama bergaul secara positif.

Bahasa yang digunakan oleh anak dalam berinteraksi dengan tetangga umumnya bahasa Sunda, sedangkan ketika berinteraksi dengan tetangga yang sebaya, sesekali digunakan bahasa Arab, seperti "Dekul...!" yang artinya mengajak masuk temannya ke dalam rumah. Beberapa kata bahasa Sunda yang digunakan untuk menyapa orang dewasa adalah: $A a$ sapaan kepada laki-laki, teteh sapaan untuk perempuan, ceu sapaan untuk perempuan yang sudah menikah, dan sapaan untuk teman sebaya dengan menyebut nama saja.

\section{Perawatan}

Bagian dari pola pengasuhan anak adalah perawatan bayi, yaitu merawat anak mulai dari memandikan, memberi makan, menjaga anak sampai menidurkan. Perawatan anak melibatkan kaum ibu. Dalam hal ini, ibu rumah tangga yang setiap hari berada di rumah akan melakukan perawatan secara langsung kepada anaknya. Terutama kaum ibu yang mempunyai anak bayi atau anak usia balita, kegiatan memandikan, memberi makan, menjaga anak, dan menidurkan merupakan kegiatan yang tidak dapat dipisahkan dari kehidupannya. Kaum ibu, dalam hal ini keturunan Arab Sunda, di Kelurahan Pasar Rebo pun demikian adanya.

Ibu rumah tangga yang mempunyai anak kecil lebih dari satu, biasanya mempunyai seorang pembantu yang kehadirannya dapat meringankan tugas ibu dalam merawat anak dan mengurus rumah. Adapun ibu yang mempunyai anak usia sekolah dapat menangani sendiri tugasnya sebagai ibu rumah tangga sehingga mereka tidak mempekerjakan pembantu di rumahnya. Selain itu, anak-anak yang sudah sekolah sudah dapat melakukan sendiri kegiatankegiatan seperti mandi, makan, dan bermain. Oleh karena itu, orang tua tidak perlu turun tangan, cukup mengingatkan dan meluruskan yang salah. Bahkan ibu yang mempunyai anak usia 10 hingga 12 tahun sudah dapat dibantu oleh anakanaknya.

Kegiatan merawat anak dapat pula dilakukan oleh kerabat dekat, nenek, bibi atau uwa, baik dari pihak ibu maupun pihak bapak, apabila tempat tinggal mereka berdekatan. Mereka dapat dilibatkan apabila ibu si anak sakit parah atau bekerja di luar rumah. Keterlibatan kerabat dalam perawatan anak tersebut karena dilandasi kedekatan. Adakalanya apabila tidak memungkinkan menitipkan anak atau melibatkan kerabat dalam merawat anak, meminta tolong tetangga terdekat.

Adapun kegiatan merawat anak dalam keluarga Arab Sunda dapat dideskripsikan sebagai berikut.

\section{a. Memandikan}

Kegiatan memandikan anak dilakukan kepada anak yang masih bayi hingga balita. Pada umumnya, ibu-ibu muda belum berani memandikan bayi sebelum luka pada bekas tali pusat mengering. Selain itu, karena badannya belum pulih sehabis melahirkan ibu tidak langsung bisa memandikan bayinya. Untuk itu, ia meminta tolong ibunya atau kerabat yang sudah berpengalaman. Bayi yang baru berumur beberapa hari hanya diseka atau dilap pada pagi dan sore hari menggunakan air hangat. Setelah diseka lalu dikeringkan menggunakan handuk yang halus. Seluruh badannya diberi minyak penghangat agar badannya menjadi hangat, lalu diberi talk. Setelah 
itu, dipakaikan baju yang terdiri atas, gurita (kain setengah dada bertali banyak) dan baju luar. Selanjutnya, bayi tersebut dibedong, yaitu dibalut oleh kain jarik. Pemakaian bedong dimaksudkan agar kedua kaki si bayi lurus tidak bengkok yang akan berpengaruh pada perkembangannya. Pemakaian gurita dimaksudkan agar bekas tali pusat tidak bergeser.

Setelah bekas tali pusat mengering, bayi mulai dimandikan oleh ibunya dengan air hangat. Kemudian pakaiannya tidak lagi menggunakan gurita, tetapi masih dua lapis yang terdiri atas kutung (baju tidak berlengan) dan baju luar. Setelah bayi itu sudah bisa duduk, maka dimandikan dengan cara didudukkan di atas waskom.

Anak yang berumur 5 hingga 6 tahun sekali-kali masih dimandikan oleh ibunya ketika akan berangkat ke sekolah. Ketika anak sudah dianggap mampu melakukan sendiri mandi dengan benar, Ibu tidak lagi memandikannya hanya mengingatkan hal-hal yang tidak boleh dilupakan anak sewaktu mandi, yaitu mengingatkan anak menggosok gigi dan memakai sabun hingga badan bersih. Terkadang ibu yang teliti, sewaktu anak baru pertamakali mandi sendiri, Ibu memeriksa gigi anaknya yang sudah digosok. Frekuensi mandi sebanyak 2 kali dalam sehari.

\section{b. Memberi Makan}

Pemberian makan disesuaikan dengan usia bayi. Para ibu di Pasar Rebo mendapat pengetahuan tentang pemberian makan bayi, baik dari pengalaman orang tua maupun dari sumber lain, seperti Posyandu setempat. Bayi hingga berusia 6 bulan diberi air susu dari ibunya saja. Pada usia di atas 6 bulan, bayi sudah diberi makanan tambahan berupa buah-buahan, yang biasa diberikan adalah buah pisang. Pemberian pi- sang kepada bayi terlebih dahulu dikerok menggunakan sendok kecil kemudian didorong air bening yang diberikan setelah pisang ditelan oleh bayi. Selain buahbuahan, diberikan pula kue biscuit agar bayi merasa kenyang karena ber-tambah umur, ASI saja tidak cukup mengenyangkan. Ketika diberi makan, sang bayi dibaringkan di atas kursi sofa atau digendong oleh ibunya menggunakan kain jarik.

Anak yang sudah bisa berjalan, diberi makan dengan cara disuapi oleh ibunya. Sebagian ibu menggendongnya dengan jarik agar anak tidak ke manamana saat disuapi. Dengan menggendongnya, penyuapan tidak akan menyulitkan ibu dan waktu penyuapan bisa lebih singkat. Cara demikian sering dilakukan oleh ibu-ibu yang sangat sibuk. Menyuapi anak dengan cara demikian bisa pula dilakukan sambil melakukan pekerjaan lain di rumah. Para ibu lainnya menyuapi anak sambil membiarkan anak bermain di tempat sehingga anak lebih mudah disuapi.

Jadwal pemberian makan untuk anak yang sudah bisa bermain di luar pagar, disesuaikan dengan kondisi anak, tetapi ibu mengupayakannya anak makan sebanyak tiga kali setiap harinya.

\section{c. Menjaga}

Anak berusia di bawah 1 tahun harus senantiasa dijaga, tidak hanya keselamatan fisiknya, tetapi keselamatan psikologisnya juga. Upaya ke arah itu sudah dilakukan oleh orang tua dengan memelihara kesehatan jabang bayi melalui perawatan rutin memeriksakan kehamilan kepada bidan atau Posyandu dan makan makanan yang bergizi menurut kemampuan. Selain itu, orang tua mengadakan pengajian pada usia kandungan menginjak 4 bulan. Dalam pengajian tersebut dibacakan ayat-ayat suci Alquran yang berkaitan dengan harapan 
mendapatkan anak yang baik, sehat, dan soleh. Sejak jabang bayi berusia 4 bulan itu ibu hamil sering membacakan ayatayat suci Alquran setiap selesai melaksanakan salat dengan harapan jabang bayi akan merasakan dan mendengar ayat-ayat suci yang dibacakan oleh ibunya. Setelah bayi lahir, dilakukan pengajian sebagai ungkapan rasa syukur dan melaksanakan kewajiban orang tua untuk mengadakan akekah menurut ajaran agama Islam.

Ketika anak mulai bisa berjalan, tugas Ibu bertambah. Berbagai peralatan rumah tangga yang dianggap akan membahayakan anak akan segera diamankan. Selain itu, Ibu tidak boleh lengah menjaga anaknya. Sebelum anak tertidur Ibu akan menunda pekerjaannya di dapur. Yang bisa Ibu kerjakan hanya pekerjaan yang bisa dilakukan sambil mengawasi anaknya. Sebagian ibu yang mempunyai anak remaja, bisa meminta bantuan anaknya yang besar untuk menjaga adiknya.

\section{d. Menidurkan}

Kemampuan menidurkan anak yang masih bayi adalah hal yang sulit dimiliki oleh ibu-ibu muda. Hal itu baru bisa dilakukan setelah Ibu hafal pembawaan anak. Anak baru bisa tidur apabila merasa nyaman. Anak yang terlalu kenyang makannya tidak akan bisa tidur, demikian pula sebaliknya, apabila belum kenyang anak tidak bisa tidur bahkan akan rewel. Hal-hal itulah di antaranya yang harus diketahui oleh ibu-ibu muda. Biasanya, apabila ibu muda tidak dapat mengatasi kerewelan anaknya, ia akan meminta bantuan orang tua atau tetangga terdekat.

Ada beberapa cara dalam menidurkan seorang bayi, di antaranya anak diberi ASI sambil tiduran hingga anak tertidur. Cara lain, bayi digendong memakai kain jarik sambil diayun-ayun hingga tetidur.
Adapun anak yang sudah tidak diberi ASI, ditidurkan dengan cara ditemani sambil diusap-usap atau ditepuk-tepuk perlahan badannya. Ibu lainnya menidurkan anak dengan membacakan cerita hingga anak tertidur. Adapula anak yang baru tidur apabila sambil mengisap susu botol. Berbagai cara menidurkan anak tersebut merupakan kebiasaan yang kemudian mengkondisikan lingkungannya

\section{Pengasuhan}

Pengasuhan anak dalam keluarga Arab Sunda dilandasi adat Islam. Pada keluarga yang ibunya berlatar belakang budaya Sunda digunakan pula tradisi Sunda pada hal-hal tertentu. Pengasuhan anak berlangsung sejak prakelahiran hingga pascakelahiran. Pada masa prakelahiran, tepatnya usia kandungan ibu 4 bulan dilakukan pengajian. Dalam pengajian tersebut, dibacakan beberapa surat seperti Surat Mariam dan Yusuf. Maksud pengajian untuk mendokan jabang bayi agar selamat. Pasca kelahiran dilakukan acara akekah, yaitu memotong kambing. Bayi laki-laki kambingnya 2 ekor, sedangkan bayi perempuan kambingnya 1 ekor. Beberapa hari kemudian dilakukan acara mencukur rambut bayi atau yang disebut marhabaan.

Pengasuhan anak usia bayi 0 tahun hingga 2 tahun sepenuhnya dilakukan oleh sang ibu karena pada masa itu bayi masih diberi ASI. Setelah anak tidak diberi ASI, pengasuhan anak dibantu oleh anggota keluarga lain. Sejak anak mulai sekolah orang tua mulai mensosialisasikan pendidikan agama.

Masyarakat Arab Sunda di Kelurahan Pasar Rebo pada umumnya bermata pencaharian sebagai pedagang, di antaranya di pasar tradisional, yaitu Pasar Rebo. Seorang Bapak sebagai kepala keluarga mempunyai kewajiban untuk mencari nafkah keluarga. Di era 
modern ini kebutuhan hidup dalam keluarga semakin meningkat sehingga Bapak mejadi lebih sibuk untuk meningkatkan pendapatannya. Sementara itu istri atau ibu yang fungsi utamanya mengurus rumah dan anak-anak dituntut harus membantu suami dalam mencari nafkah. Adanya pergeseran tersebut, menimbulkan perubahan dalam hubungan keluarga. Keeratan hubungan dalam keluarga menjadi longgar. Intensitas pertemuan orang tua dengan anak-anak menjadi berkurang sehingga komunikasi pun praktis menjadi berkurang. Hal itu menjadi kendala bagi orang tua dalam menanamkan nilai-nilai kedisiplinan kepada anak. Meskipun demikian, pada sebagian orang tua melibatkan kerabat, seperti nenek, kakek atau orang lain seperti pembantu rumah tangga untuk mengisi kekosongan selama mereka tidak ada di rumah dalam mendampingi anak. Cara lain, dengan mempersiapkan atau melatih anak agar dapat bertanggung jawab sendiri sedini mungkin.

Seorang Bapak yang sehariharinya berdagang, meninggalkan rumah hampir separuh hari. Demikian pula ibu yang membantu bapak berdagang pun sama. Namun demikian, ibu yang mempunyai anak usia Balita biasanya menyempatkan pulang dahulu ke rumah karena lokasi pasar tidak terpaut jauh dari pemukiman. Biasanya, sebelum meninggalkan rumah dan anak-anak, terlebih dahulu Ibu mengerjakan sebagian pekerjaan, seperti memasak, mencuci, dan membersihkan rumah selama masih sempat. Apalagi mempunyai anak yang masih berusia Balita, pekerjaan tersebut dilakukan sambil mengurus si kecil. Menjelang waktu subuh, Bapak sudah berangkat ke masjid untuk melaksanakan salat subuh secara berjamaah. Apabila mempunyai anak laki-laki, biasanya mengajaknya ke masjid.

\section{a. Disiplin Kebersihan Diri}

Sejak usia 2 tahun anak sudah mulai dapat melakukan buang air kecil dan air besar dengan bimbingan ibunya. Apabila anak menunjukkan tanda-tanda akan buang air kecil atau besar, ibu membawanya ke kamar kecil. Ketika anak akan melakukannya Ibu menyuruh anak untuk berjongkok. Kecuali anak laki-laki kalau buang air kecil disuruh berdiri. Proses tersebut berlangsung hingga usia 4 tahun. Selanjutnya, anak dapat dilepas melakukannya sendiri. Setelah anak bisa melakukan sendiri, ibu tetap memantau sampai anak tahu betul yang harus dilakukannya ketika buang air besar dan kecil.

Tata cara melakukan mandi diajarkan kepada anak saat ibu memandikannya. Kegiatan yang berlangsung setiap hari tersebut terekam dalam memori anak sehingga anak dapat mengikutinya saat anak mulai mandi sendiri. Ketika anak beranjak remaja, kebersihan lebih diperhatikan lagi. Khususnya mendampingi anak perempuan saat memasuki usia balig.

\section{b. Disiplin Makan Minum}

Makan minum merupakan kebutuhan pokok manusia yang tidak dapat ditunda-tunda. Manusia melakukan berbagai cara untuk memenuhi kebutuhan pokok tersebut. Pada umumnya keluarga keturunan Arab Sunda termasuk golongan ekonomi menengah. Dalam memenuhi kebutuhan hidupnya, mereka bekerja keras dengan membuka usaha perdagangan pakaian atau elektronik atau reparasi jam.

Setiap keluarga mengakui bahwa mereka membutuhkan makan untuk mengisi energi mereka dengan makan paling sedikit 3 kali dalam sehari dengan menu sesuai kemampuan. Untuk anak orang tua menyediakan makan dengan lauk-pauk yang disukai anak. Kegiatan 
makan tidak bisa dilakukan bersamasama mengingat aktivitas keluarga tidak sama. Terkadang anak yang sekolah pagi sarapan lebih dahulu. Bapak yang berjualan di pasar makanannya dibekal ke pasar.

Pada umumnya anak-anak suka jajan di warung meskipun sudah makan di rumahnya, maka setiap hari Ibu atau Bapak memberi uang jajan, baik kepada anak yang sudah sekolah maupun belum. Sebagian ibu yang mempunyai banyak waktu luang terkadang membuat penganan yang menjadi kesukaan anaknya dengan harapan keinginan jajan anaknya dapat ditekan. Dalam menanamkan disiplin makan minum orang tua sangat berperanan. Sejak kecil anak sudah diarahkan melakukan makam dan minum secara tertib dengan memperhatikan halhal sebagai berikut:

- Makan dan minum dilakukan tidak tergesa-gesa;

- Mencuci tangan sebelum makan;

- Sebelum dan sesudah makan berdoa dahulu;

- Makan harus sambil duduk, tidak boleh berjalan-jalan;

- Memperhatikan sunah Nabi yakni berhenti makan sebelum kenyang;

- Minum air tidak boleh ditotor dari teko;

- Makan tidak boleh sambil bernyanyi-nyanyi; dan

- Mengunyah makanan tidak boleh sambil berbicara.

\section{c. Disiplin Tidur/ Istirahat}

Kegiatan tidur pada siang hari dilakukan untuk menjaga stamina. Hal itu banyak dilakukan orang dewasa di Nagri Kidul yang masih aktif bekerja. Setiap orang tidak sama waktu untuk tidur siang. Bagi orang yang masih bekerja, beristirahat pada sore hari, sedangkan orang yang sudah pensiun melakukannya setelah melaksanakan salat Dhuha. Lama melakukan tidur pada siang hari bervariasi, berkisar 30 menit hingga 1 jam. Demikian pentingnya beristirahat pada siang hari membuat sebagian orang merasa keberatan menerima tamu pada jam-jam tertentu.

Istirahat dengan melakukan tidur juga diterapkan kepada anak-anak, terutama anak usia 0-5 tahun. Anak-anak pun demikian, pada siang hari selama kurang lebih 1-2 jam anak melakukan tidur siang karena anak usia 0 hingga 5 tahun sering rewel apabila kurang beristirahat.

Meskipun tidak semua anak melakukannya, ada beberapa hal terkait yang biasa ditekankan oleh orang tua kepada anak, antara lain:

- Tidak boleh tidur pada saat waktu salat tiba;

- Sebelum tidur harus mencuci kaki dan gosok gigi;

- Sebelum tidur harus buang air kecil dulu;

- Berdoa sebelum tidur;

- Harus bangun pada saat waktu salat Subuh tiba; dan

- Bangun tidur harus membereskan tempat tidur.

Kegiatan sehari-hari anak usia sekolah adalah belajar dan bermain. Selain itu, anak-anak Nagri Kidul melakukan kegiatan lain, yaitu belajar mengaji di masjid atau madrasah. Khususnya anak laki-laki selain belajar mengaji, melaksanakan salat berjamaah di masjid pada hari Jumat, terkadang turut Bapaknya berziarah ke makam leluhur yang lokasi makamnya cukup dekat dengan tempat tinggal. Waktu tidur anak pada malam hari sekitar pukul 19.00 WIB - 20.00 WIB dan bangun ketika Subuh. Biasanya, anak laki-laki remaja melaksanakan salat Subuh di masjid terdekat, sedangkan anak perempuan salat Subuh di rumah masing-masing. 


\section{d. Disiplin Bermain}

Masyarakat Arab Sunda di Nagri Kidul tinggal di wilayah perkotaan sehingga jenis permainan yang dimainkan oleh anak-anak tidak seperti permainan anak-anak di pedesaan yang menggunakan sarana dan media bermain sederhana dan berasal dari lingkungan sekitar tempat tinggal.

Permainan yang dimainkan oleh anak-anak dari keluarga Arab Sunda misalnya bulu tangkis yang menggunakan peralatan lengkap seperti raket dan kok. Adapun tempat bermain di tempat-tempat luas, seperti areal parkir depan kantor desa atau depan rumah yang memiliki halaman luas. Permainan lainnya biasanya muncul secara musiman, seperti permainan layang-layang dan kelereng yang biasa dimainkan oleh anak laki-laki. Adapun anak perempuan usia 2 hingga 9 tahun umumnya bermain bone$\mathrm{ka}$, rumah-rumahan dengan perlengkapan boneka dan lain-lainnya yang dibeli dari toko atau pasar. Anak yang lebih besar sedikit biasanya bermain loncat tinggi menggunakan karet gelang atau bermain congkak dan beklen menggunakan sejumlah kuwuk.

Adapun anak-anak remaja, baik laki-laki maupun perempuan, banyak yang terampil mengendarai sepeda motor. Keterampilan tersebut dinikmatinya sebagai salah satu media bermain dalam pergaulan. Sepeda motor menjadi alat transportasi yang membawanya ke rumah teman-temannya yang sebenarnya rumah mereka berdekatan. Selain berkeluyuran menggunakan sepeda motor, anak remaja laki-laki senang berkumpul dengan sesamanya sambil bermain gitar. Ada pula kelompok lakilaki dengan sepengetahuan orang tua menginap di vila milik keluarga temannya. Berbeda halnya dengan remaja kelompok perempuan, mereka tidak diizinkan oleh orang tuanya berkeluyuran di jalan. Bahkan mereka tidak boleh keluar rumah pada malam hari tanpa ditemani orang dewasa.

\section{e. Disiplin Belajar}

Dalam masyarakat keturunan Arab Sunda regenerasi menjadi salah satu hal yang sangat penting. Dengan memberikan pengetahuan dan keterampilan sedini mungkin kepada anak, orang tua mendapat manfaat yang cukup besar. Terutama anak yang beranjak remaja sudah dapat membantu orang tua, baik di rumah maupun di luar. Baik anak lakilaki maupun anak perempuan, diberi tanggung jawab masing-masing dalam memelihara rumah. Orang tua yang mengelola sebuah usaha, misalnya usaha pengolahan makanan, melibatkan anak perempuan dalam proses pembuatan, sedangkan anak laki-laki mengantar pesanan ke toko-toko.

Disiplin belajar merupakan salah satu penanaman disiplin untuk berbagai perilaku anak pada masyarakat. Penanaman disiplin ini sudah dimulai pada saat anak mulai bisa berkomunikasi. Sejak kecil anak didorong belajar mengaji dan menghapal doa-doa. Orang tua senantiasa menasihati anak tentang norma-norma dan sopan santun melalui contoh-contoh. Cara memberikan nasihat dilakukan secara spontan pada saat anak akan melakukan sesuatu atau saat anak melakukan kesalahan. Dengan kata lain, cara pemberian nasihat dilakukan secara terus-menerus. Dalam keluarga keturunan Arab Sunda unsur ajaran agama Islam cukup menonjol. Norma-norma tersebut di antaranya sebagai berikut:

- Hormat dan patuh kepada orang tua;

- Hormat dan patuh kepada orang yang lebih tua;

- Bersikap baik kepada orang lain;

- Sayang dan melindungi adik; 
- Membiasakan mengucapkan salam apabila memasuki rumah;

- Membiasakan mengucapkan permisi apabila melintasi orang lain;

- Membiasakan mengucapkan terima kasih apabila menerima pemberian orang;

- Membiasakan mengucapkan terima kasih apabila ditolong orang lain; dan

- Perempuan yang sedang haid dilarang beribadah salat dan puasa.

\section{Penutup}

Setiap anak yang lahir ke dunia secara naluri ingin dipenuhi kebutuhan biologis dan sosialnya. Kedua aspek kebutuhan anak tersebut dapat dicapai melalui proses sosialisasi atau pola pengasuhan anak yang menjadi tanggung jawab orang tuanya. Adapun setiap kelompok masyarakat memiliki cara masing-masing dalam melaksanakan pengasuhan kepada anak yang dipengaruhi oleh karakter budaya dan sosial masing-masing.

Proses sosialisasi berawal dari lingkungan keluarga inti yang terdiri atas bapak, ibu, dan anak. Dalam proses sosialisasi terjadi pola interaksi antaranggota keluarga. Proses sosialisasi dalam suatu keluarga turut menentukan perkembangan karakter anak. Oleh karena itu, keluarga inti merupakan lembaga sosial terkecil yang kedudukan dan perannya dalam proses sosialisasi nilainilai kepada anak amatlah penting. Hubungan timbal-balik dalam keluarga dapat memperkuat rasa kekeluargaan.

Pengalaman anak berinteraksi dengan orang tua dan saudara kandung akan menjadi bekal bagi dirinya ketika berinteraksi secara luas dalam masyarakat. Seseorang yang sudah berbaur dalam lingkungan masyarakat mulai menerima nilai-nilai sosial dan budaya baru dari lingkungan sosialnya. Dalam masyarakat seseorang akan berhadapan dengan aturan-aturan yang berlaku pada masyarakat. Berbagai benturan nilai dalam proses beradaptasi akan menempa aspek psikologis anak yang akhirnya akan mematangkan kepri-badiannya.

Demikian pula halnya pola pengasuhan anak pada masyarakat Arab Sunda di Kelurahan Nagri Kidul, Kecamatan Purwakarta berawal dari keluarga inti. Percampuran budaya orang tua sebagai tokoh sentral dalam proses sosialisasi nilai-nilai turut mempengaruhi perkembangan karakter anak. Orang tua campuran yang berlatar belakang dua budaya, dalam hal ini Arab dan Sunda, mengasuh dan mendidik anaknya dengan mensosialisasikan nilai-nilai yang relevan dari kedua budaya mereka. Perbedaan budaya bagi pasangan suami istri keturunan Arab Sunda tersebut sudah disadari sejak mereka memutuskan berumah tangga.

Nilai-nilai yang bersumber dari budaya Arab dan budaya Sunda yang diterapkan dalam keluarga keturunan Arab Sunda dapat saling melengkapi. Orang tua mensosialisasikan nilai-nilai dari kedua budaya tersebut melalui perilaku sehari-hari. Masyarakat Arab Sunda di wilayah ini menganut agama yang sama sehingga nilai-nilai yang mereka praktikkan dilandasi nilai-nilai agama.

Ibu yang umumnya berada di rumah memiliki banyak kesempatan berinteraksi dengan anak dibandingkan dengan Bapak sehingga nilai-nilai yang bersumber dari Ibu lebih deras diterima anak. Sebaliknya, Bapak sebagai pencari nafkah sebagian besar waktunya tidak berada di rumah sehingga nilai-nilai dari Bapak tidak sederas dari Ibu.

Pendidikan dan pengasuhan anak pada keluarga keturunan Arab Sunda lebih dititkberatkan pada pensosialisasian ajaran agama daripada nilai-nilai tradisi. Namun demikian, tidak berarti mereka 
tidak mengetahui tradisi. Pada kenyataannya, sebagian anak yang lebih didominasi darah Sunda mengetahui peribahasa Sunda dan tidak asing pula dengan obat-obatan tradisional yang biasa digunakan oleh orang Sunda. Jenis pendidikan yang diberikan kepada anak berpengaruh pula pada sikap dan perilaku anak ketika menginjak usia dewasa, baik anak lakilaki maupun anak perempuan.

\section{DAFTAR PUSTAKA}

Adimihardja, Kusnaka dan Djuariah M.Uca. 1991/1992.

Pola Pengasuhan Anak Secara Tradisional pada Orang Sunda. Bandung: Proyek Inventarisasi dan Pembinaan Nilai-nilai Budaya.

Badan Pariwisata Kabupaten Purwakarta. 2006.

Ekspedisi Purwacinta, Inventarisasi dan Dokumentasi Situs Kepurbakalaan. Purwakarta: Pictura Artmodif Studio.
Intani, Ria. 2005.

Pola Pengasuhan Anak pada Masyarakat Betawi. Bandung: Balai Kajian Sejarah dan Nilai Tradisional Bandung.

Koentjaraningrat. 1974.

Kebudayaan, Mentalitas dan Pembangunan. Jakarta: Gramedia.

Shm., Suhandi. 1991.

Pola Hidup Masyarakat Indonesia. Bandung: Jurusan Antropologi UNPAD.

Soekanto, Soerjono. 1982.

Sosiologi Suatu Pengantar. Jakarta: Rajawali.

http://id.wikipedia.org/wiki/Purwakarta,Purwakarta

http://purwakarta.go.id/kondisi.php

http://www.purwakarta.go.id/ pariwisata.php 